Open Access

\title{
The land grabbing in the international scenario: the role of the EU in land grabbing
}

\author{
Anna Carroccio*, Maria Crescimanno, Antonino Galati and Antonio Tulone
}

\author{
* Correspondence: \\ annacarroccio@gmail.com \\ This paper has been selected as a \\ best paper of the 51th SIDEA \\ Conference in Benevento (18-20 \\ September 2014). It has been \\ accepted for publication in this \\ journal following the usual revision \\ process. \\ Department of Agricultural and \\ Forest Sciences, Università degli \\ Studi di Palermo, Palermo 90128, \\ Italy
}

\begin{abstract}
The worldwide increase in population and consumption has produced a growing demand for food and energy in the rich and developing Countries. The resulting intensification of land investments, to cope with this need, has in many cases produced investments without transparency rules and it hasn't created real development for local people. The aim of this paper is to identify, through a cluster analysis, homogeneous groups of investor Countries in order to understand the role of the EU Member States in the context of land grabbing. The results show that the strategies adopted by the investors are driven by the need to achieve energy security and reduce $\mathrm{CO}_{2}$ emissions in order to cope with the problems of food security and to adopt the proposals and the objectives of the European Union Policy for Sustainability. In particular, the acquisitions of EU Member States are driven by the need to provide enough food for the exponential growth of the population and to reduce the energy deficit in view of the achievement of the objectives set out in the "Europe 2020".
\end{abstract}

Keywords: Land grabbing, EU investor Countries, Food security, Energy security, European Union Policy

\section{Background}

The land grabbing phenomenon has prompted a lively and wide-ranging scientific debate about its alarming spread and the implications for economic, political, ethical, and social issues. The term "land grabbing" indeed, describes large-scale and long-term farmland acquisition below the real market values, and it is also strongly correlated with the political, social, economic and environmental aspects of nations and people in the world.

The land grabbing covers several European Union (EU) Member States, not only as investors but also, more recently, as recipients. Regarding EU investor Countries, the relationship between land grabbing and European policies for agriculture and environment is very close. Every action and commitment made by the $\mathrm{EU}$ in policies to reduce carbon dioxide $\left(\mathrm{CO}_{2}\right)$ emissions in the fight against climate change and in food and energy policies have a common denominator: soil resources (European Commission 2008, 2010a, b; United Nations 1992a, b, 1998). The achievement of international goals for decarbonisation has pushed for the use of renewable energy and biofuels but the

(C) 2016 Carroccio et al. Open Access This article is distributed under the terms of the Creative Commons Attribution 4.0 International License (http://creativecommons.org/licenses/by/4.0/), which permits unrestricted use, distribution, and reproduction in any medium, provided you give appropriate credit to the original author(s) and the source, provide a link to the Creative Commons license, and indicate if changes were made. 
context has created a lively discussion on the intended use of the land. Today, biofuels are among the stronger competitors in the usage of arable areas for foods (European Commission 2006, 2010a, b; FAO 2013).

With this in mind, the aim of this study is to identify homogeneous groups of investor Countries, among 57 world countries. The sample was selected based on available data, taking into account transnational investments only and ignoring domestic land acquisition. This classification allows us to assess the role of EU Member States in the international land-grabbing scenario.

\section{Literature review}

According with the Tirana Declaration land is "grabbed" when land deals occur under one or more of the following points: "(i) in violation of human rights, particularly the equal rights of women; (ii) not based on free, prior and informed consent of the affected land-users; (iii) not based on a thorough assessment, or are in disregard of social, economic and environmental impacts, including the way they are gendered; (iv) not based on transparent contracts that specify clear and binding commitments about activities, employment and benefits sharing, and; (v) not based on effective democratic planning, independent oversight and meaningful participation" (International Land Coalition 2011, p. 2).

The phenomenon stems largely from world population growth, today approximately 7 billion and estimated to be 9 billion in 2050 (FAO 2013), with consequent need of food and energy consumption (including renewable energy) and growth of insecurity. This is true, in particular, in many African countries where in the last few years was registered a growing food insecurity in cereals due to rapid increase of population and urbanisation process (Galati et al. 2014). In the last few decades, the need to achieve food and energy security has been among the reasons that pushed governments and multinational corporations to search for land in which to invest. Other reasons are: the need to exert more control on the global market, especially for scarce resources such as water and soil; ensure economic viability and social stability of their own governments; expand and diversify company and investment funds (Buxton et al. 2012; Deininger and Byerlee 2011). However, according to De Castro (2011) the problem of the 'new scarcity' of food cannot be explained only by analyzing the demographics and production, but rather looking at the unequal distribution of basic resources such as land, livelihoods and 'know-how'. Land grabbing takes place mainly in underdeveloped and developing countries that are, thus, exploited and become further impoverished and robbed of not only of their environment but also of human capital. As asserted by Zagema (2011), the populations of the areas affected by land grabbing are frequently forced into exile without being able to claim the right of ownership of their land. In general, the contracts provide acquisitions or leases of vast fertile areas for periods between 25 and 99 years, with rents that can range from $€ 0.60$ to $€ 16$ per hectare and per year (Liberti 2011). On the other hand, the recipient governments consent is mainly due to opportunities to benefit from transnational capital to start processes of growth and modernization through the creation of jobs, the production of cash crops and the construction of infrastructure (Cotula et al. 2009; Lavers 2012). As suggested by Longhitano (2010) the negotiations exploit the particularly favourable conditions of the land market in developing countries, on account of the lack of certainty regarding property rights, and appeal to local governments for potential returns in terms of infrastructure and increase in GDP and employment rates. 
According to the Land Matrix Global Observatory, ${ }^{1}$ the area covered by large-scale investments entered into by foreign investors is almost 35 million hectares (The Land Matrix Global Observatory 2014). All continents are involved, the largest share of acquired land is concentred in the Sub-Saharan Africa (Deininger and Byerlee 2011).

The World Bank maintains that the increasing global interest in agriculture is a serious threat to small farmers in developing countries, because of the problems that could stem from their inability to gain access to land and natural resources. On the other hand, the World Bank also considers these 'dangerous investments' as an opportunity for development of poor countries (Deininger and Byerlee 2011).

Some authors wonder if land grabbing phenomenon is a form of neo-colonialism or if it is instead an opportunity for development of developing countries.

Da Vià (2011) argues that the land grabbing is a win-win situation, that is as a good situation for everyone involved; this is a way to legitimize a model of agricultural development characterized by neo-liberalism, which aims to promote "policies geared toward the concentration of corporate power in the food system, the expansion of 'value chains', the commodification of land and labour, and the removal of public interventions such as price controls and subsidies to small producers".

By contrast, a model which is based on large-scale land acquisition seriously endangers the local communities. These often suffer for the higher costs of such a policy which does not take account of those who traditionally hold the land for customary law, and therefore cannot claim property rights that are legally relevant (Alden et al. 2012).

These diverse standpoints are summarised by De Schutter (2011) and Robertson and Pinstrup-Andersen (2010), who think that investments in agriculture by foreign investors are an important tool in raising the economies of poor countries, provided that populations' human rights are respected and that they are involved in the deals. This approach would allow them to decide their future and, thus, avoid the development of problems regarding food security and nutrition which are strictly connected to their ability to gain access to land.

In this debate, De Castro (2011) states that land grabbing is one of the issues that require quick and effective solutions in order to ensure food security and fundamental rights for current and future generations. He adds that we need a shared commitment by the political and civil society in the search for new models marked by solidarity, sustainability and ethical use of natural resources. These models provide for the involvement of more about 500 million small farmers in developing countries, to enhance the food security of the people and reducing social instability in these countries at the same time.

\section{Methods}

In order to identify homogeneous groups of investor Countries and the role of the EU Member States in the international scenario of land grabbing, we used the cluster analysis both to identify specific market segments, and to analyse socio-economic disparities among territories. In this first step we have identified 26 socio-economic and environmental variables related to the land grabbing phenomenon, such as the average dietary energy supply adequacy, political stability and absence of violence/terrorism, energy production, GDP per capita, etc., according to the economic literature (Von Witzke and Noleppa 2010; Borras et al. 2011; Borras and Franco 2011, 
2012; Hall 2011; Matondi et al. 2011; Cotula 2012; Rulli et al. 2012; Scheidel and Sorman 2012; Margulis et al. 2013; McMichaela 2013). The sources used are data sets from Land Matrix, the World Bank, and the Food and Agriculture Organization (FAO 2014). Eleven variables have been excluded for the lack of data both for all the 57 investor Countries considered and for the entire 2000-2013 period. At the end of this preliminary phase, the socio-economic and environmental variables that we have used in this work are the following five:

- The variable Land_grab_size, from Land Matrix ${ }^{1}$ database, expresses the surface acquired by transnational investors in foreign countries in the period 2000-2013;

- The variable $\mathrm{CO}_{2}$ from World Bank data, is the amount of $\mathrm{CO}_{2}$ emissions stemming from the burning of fossil fuels and manufacture of cement during the period 2000-2013;

- The variable per capita agro-forestry surface (Agr_For_Pop) expresses the available per inhabitant land to carry out activities in the agricultural and forestry sectors. The data were obtained from sources of the FAO and refer to the period 2000-2013;

- The variable Energy_dep is the amount of energy imported, measured as a percentage of total energy use. The data were obtained from the site of the World Bank. The reference period is from 2000 to 2013;

- The variable Amv_Pop expresses the average annual rate of change of population in the 2000-2050 period and was obtained from the data published by FAO.

On the basis of the described variables, we conducted the cluster analysis -using SPSS 17 , to identify homogeneous groups of countries. All the variables used have been standardised, both for the purpose of this analysis and to delete existing differences among the measurement units. The cluster analyses starts with a hierarchical method which yields the suitable number of clusters and the group of centroids. In the second step, the clusters are refined further using a non-hierarchical method - the k-means - which maximises the Euclidean distance between cluster centres while minimising the distance between members of any given cluster. In order to verify which is the better elaboration to classify the countries studied, different elaborations are carried out by varying the number of clusters, up until a number is identified such that additional groups contain only a few countries with significant short distances. Previously, an analysis of the correlation coefficients was performed in order to eliminate redundant variables (e.g. the food dependency index). Furthermore, in order to make the comparison across all variables simultaneously and to track the ranking of the groups, we have considered the standardised average values from the variance matrix, to overcome the constraint linked to the different units of measurement without losing the variation between the values.

\section{Results}

As we can see in Tables 1 and 2 and in Fig. 1, there is a significant concentration of EU Member States (14 of 17 investors) in the first cluster. This cluster includes 42 countries with lower average values than the other clusters for surfaces acquired, $\mathrm{CO}_{2}$ emissions and rate of population growth. On the contrary, these countries show high energy dependency and low agricultural and forestry area per capita. As suggested by 
Table 1 Groups of countries identified by the cluster analysis ( $k$-means method)

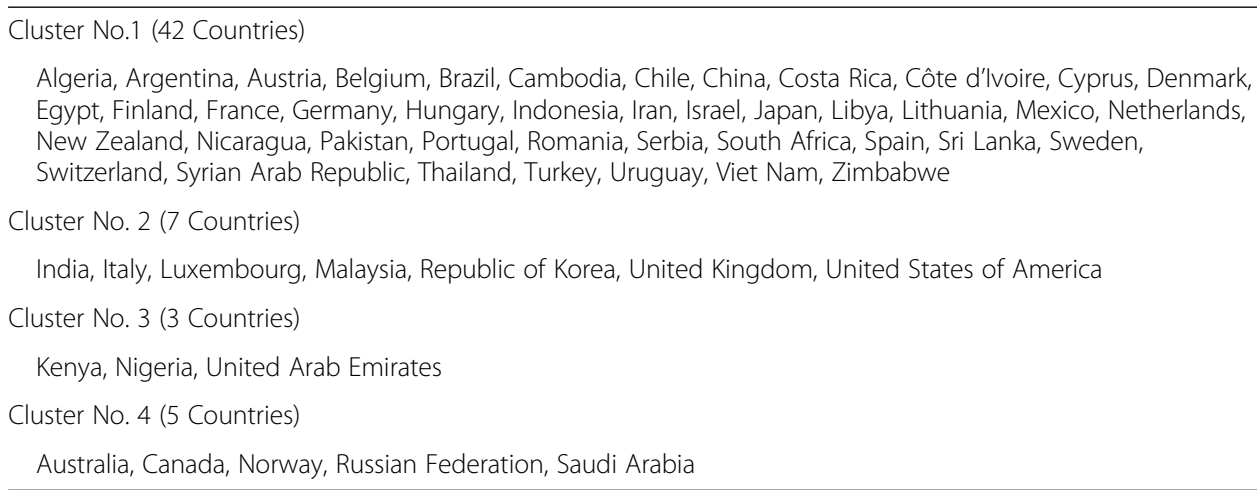

Scheidel and Sorman (2012), the energy security threats are the drivers to acquire land for the expansion of energy systems, especially in the presence of low availability of arable land.

This result helps to explain the common behaviour of many investors of the EU Member States area, which are almost entirely characterised by energy deficits and have committed to achieve the European objectives of utilizing at least the $20 \%$ of renewable energy before 2020. However, inside this group, there are some countries that are self-sufficient in terms of energy and that are, in fact, energy exporters; these countries, despite their high rates of population growth, have acquired limited foreign areas.

The second cluster comprises seven countries (including three EU Member States) with the highest acquired surfaces and high energy dependence compared to the first cluster. They are also inclined to higher average values of $\mathrm{CO}_{2}$ emissions. In addition, this group includes many countries that have limited availability of land per capita, which is one of the key factors behind pushes to acquire arable land. Spieldoch and Murphy (2009) emphasise that countries plagued by natural resource constraints (e.g. deficiencies in arable land) are the major exploiters of natural resources abroad. The acquisition of arable land, mainly in the Global South, aims to establish tree plantations wholly or partly for biomass energy for export or for domestic markets, to reduce greenhouse gas emissions (Cotula 2011, 2012) and, as in the case of India and Korea, to produce food for their growing populations (Hall 2011).

The Cluster 3 contains three countries characterised mainly by high rates of population growth compared to the average of the groups. Among these United Arab Emirates show a high level of acquisition. The link between demand for land and population growth, mainly in high- and middle-income countries, has been emphasised by different authors (i.e., Cotula et al. 2009; Robertson and Pinstrup-Andersen 2010). In

Table 2 Cluster distance: k-means method

\begin{tabular}{|c|c|c|c|c|c|}
\hline \multirow[t]{2}{*}{ Cluster name } & \multirow[t]{2}{*}{ No. } & \multicolumn{4}{|c|}{ Cluster No. } \\
\hline & & 1 & 2 & 3 & 4 \\
\hline Countries with a low agro-forestry land per capita & 1 & 0 & 2.476 & 3.830 & 3.701 \\
\hline Countries with a higher rates of investment & 2 & 2.476 & 0 & 4.085 & 3.990 \\
\hline Countries with a higher rate of population growth & 3 & 3.830 & 4.085 & 0 & 4.692 \\
\hline Countries with a higher rate of $\mathrm{CO}_{2}$ emissions & 4 & 3.701 & 3.990 & 4.692 & 0 \\
\hline Average & & 2.502 & 2.638 & 3.152 & 3.096 \\
\hline
\end{tabular}




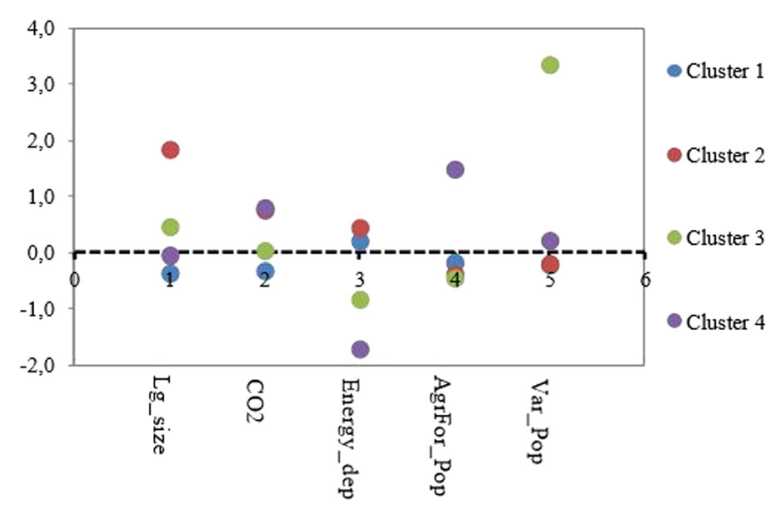

Fig. 1 Average values for each cluster based on standardized values

fact, the increase of population has stoked an increasing pressure on land use for subsistence, potentially depriving the poor populations of their ability to support themselves (Cotula et al. 2009). These countries probably invest for a future perspective of food insecurity, which has prompted corporate investment in food crops and in energy security (Godfray et al. 2010; White et al. 2012).

Finally, in the Cluster 4, there are five countries that are self-sufficient in terms of energy but that, in contrast, exhibit high $\mathrm{CO}_{2}$ emissions, which is one of the main motivations behind the acquisition of productive land in foreign countries. This group has many countries with the greatest obligations to reduce emissions, according with the Annex B of the Kyoto Protocol (United Nations 1998). As asserted by Peters et al. (2011), these countries have shifted an increasing proportion of their $\mathrm{CO}_{2}$ emissions to countries without emissions ceilings.

The analysis of the differences between the F-ratios makes it possible to draw general conclusions about the role of the different mean variables in the forming of the clusters. The results show that the average annual rate of change of population and investment size have great influence on the formation of the cluster, followed by the per capita agro-forestry surface and then by the $\mathrm{CO}_{2}$ emission and energy dependence variables.

\section{Discussion and conclusions}

The main aim of this work was to identify the drivers of the choices of the investor Countries and assess whether EU Member States assume common behaviour in land grabbing scenario. The results showed that is possible to identify homogeneous groups of countries according to socio-economic and environmental variables observed. In particular, the EU Member Countries (Cluster 1) are characterized by the need to reduce the energy deficit and the $\mathrm{CO}_{2}$ emissions to achieve the 'Europe 2020 Strategy', although, as our findings suggest, they are characterized by a lower levels of $\mathrm{CO}_{2}$ emissions compared to other countries. This can be explained by the increasing interest for European Union policies to safeguard the environment and combat climate change. In fact, the EU as part of the 'Europe 2020 Strategy', decided unilaterally to achieve specific goals by 2020 as the reduction of $\mathrm{CO}_{2}$ emissions by $20 \%$ compared to 1990 and to obtain $20 \%$ of energy needs from sources of renewable energy (European Commission 2010a, b). These facts have led and developed the EU policy on bio fuels, creating a 
market and building the foundation for the development of agro-industrial bio fuels in the EU and in developing countries (Franco et al. 2010). This approach, at least in appearances, bases its foundations on three essential elements that are greater energy security, reduction of greenhouse gases and rural development in developing countries (Borras and Franco 2011; Franco et al. 2010; Aubry 2012).

As mentioned by Aubry (2012), the EU policy on bio fuels is an important driver of land grabbing in Africa as evidence the increase in demand for land to produce bio fuels and export them to the European Countries. If you add to this the increase in palm oil investments in some of the Southeast Asia regions since the adoption in 2008 in the European Parliament's mandatory quota of $10 \%$ of green fuel in the transport sector (Pye 2010), we can easily deduce the strong link between land grabbing and European policies. Crops such as maize, oil palm or cane sugar for bio fuel production need, in fact, of large tracts of land that are the basis for the development of phenomena related to land grabbing (Aubry 2012); Aubry argues that the positive impact provided by the Renewable Energy Directive, in fact, gives assurances only on environmental sustainability criteria and does not prevent the negative social impacts with the grave danger of opening the doors to possible cases of land grabbing.

In general, the four groups of countries identified highlight that the strategies adopted by the investors are driven by the need to achieve energy security and reduce $\mathrm{CO}_{2}$ emissions (Clusters 1, 2, and 4) and to resolve food security problems (Cluster 3) linked to exponential population growth. A central role in this complex phenomenon is played by the international agricultural and environmental policies (particularly those related to climate change and to strategic programs for energy).

The research results were affected by the variables considered, whose choice was dictated by the need to have complete data for all the investor Countries and for all the studied period (2000-2013). Nevertheless, the results offer a contribution to the research on land grabbing. Up to now, studies about this phenomenon were focused on recipient Countries, overlooking the role of investors. However, a greater detail regarding to the size of the investment type in agriculture, forestry or energy (data not available in international databases) could allow the study to give a bigger acknowledgment and explanations of the specificity within individual clusters identified.

\section{Endnotes}

1 "The Global Observatory includes deals that are made for agricultural production, timber extraction, carbon trading, industry, renewable energy production, conservation, and tourism in low- and middle-income countries. Deals must: entail a transfer of rights to use, control or ownership of land through sale, lease or concession; have been initiated since the year 2000; cover an area of 200 hectares or more; imply the potential conversion of land from smallholder production, local community use or important ecosystem service provision to commercial use" (The Land Matrix Global Observatory 2014).

Abbreviations

Agr_For_Pop: per capita agricultural and forest area; Amv_Pop: population growth rate; $\mathrm{CO}_{2}$ : carbon dioxide; Energy dep: energy imports, net (\% of energy use); et al.: et alii; EU: European Union; FAO: Food and Agriculture Organization; GDP: Gross Domestic Product; i. e.: id est; No.: Number. 


\section{Authors' contributions}

The research group of this study analysed and interpreted data and prepared the research article. All authors read and approved the final manuscript.

\section{Authors' information}

The authors of this work are members of the Università degli Studi di Palermo (Italy):

Anna Carroccio, PhD in Economics and agricultural Policy, Department of Agricultural and Forest Sciences, University of Palermo, Viale delle Scienze, Building 4, 90128 Palermo;

Maria Crescimanno, Full Professor in Agricultural Economics and Valuation, Department of Agricultural and Forest Sciences, University of Palermo, Viale delle Scienze, Building 4, 90128 Palermo;

Antonino Galati, PhD Researcher in Agricultural Economics and Valuation, Department of Agricultural and Forest Sciences, University of Palermo, Viale delle Scienze, Building 4, 90128 Palermo:

Antonio Tulone, Doctor in Agricultural Engineering, Palermo, Italy.

\section{Acknowledgements}

The authors thank the Program Committee which selected our work "Land grabbing models in the international scenario: the case study of the European Union", for publication on ordinary number of the journal Agricultural and Food Economics (Springer and), dedicated to the LI Conference SIDEA 2014.

Received: 29 November 2014 Accepted: 8 April 2016

Published online: 14 April 2016

\section{References}

Alden WL, Anseeuw W, Cotula L, Taylor M (2012) Land rights and the rush for land: findings of the global commercial pressures on land research project. ILC, Rome

Aubry S (2012) (Bio) fuelling injustice? Europe's responsibility to counter climate change without provoking land grabbing and compounding food insecurity in Africa. EuropAfrica, Terra Nuova, Rome

Borras SM Jr, Franco JC (2011) Political dynamics of land grabbing in Southeast Asia: understanding Europe's role. Transnational Institute, Amsterdam

Borras SM Jr, Franco JC (2012) Global land grabbing and trajectories of agrarian change: a preliminary analysis. J Agrar Chang 12(1):34-59

Borras SM Jr, Hall R, Scoones I, White B, Wolford W (2011) Towards a better understanding of global land grabbing: an editorial introduction. J Peasant Stud 38(2):209-216

Buxton A, Campanale M, Cotula L (2012) Farms and funds: investment funds in the global land rush., lied Briefing - The global land rush, Available at http://pubs.iied.org/pdfs/17121IIED.pdf. Accessed 2 May 2014

Cotula L (2011) Biomass energy: another driver of land acquisitions?., lied Briefing - The global land rush, Available at http://pubs.iied.org/pdfs/17098IIED.pdf. Accessed 12 May 2014

Cotula L (2012) The international political economy of the global land rush: a critical appraisal of trends, scale, geography and drivers. J Peasant Stud 39(3-4):649-680

Cotula L, Vermeulen S, Leonard R, Keeley J (2009) Land grab or development opportunity? Agricultural investment and international land deals in Africa. IIED/FAO/IFAD, London/Rome

Da Vià E (2011) The politics of "Win-Win" narratives: land grabs as development opportunity? University of Sussex, Sussex, UK

De Castro P (2011) Corsa alla terra. Cibo e agricoltura nell'era della nuova scarsità. Donzelli, Rome

De Schutter $\mathrm{O}$ (2011) How not to think of land-grabbing: three critiques of large-scale investments in farmland. J Peasant Stud 38(2):249-279

Deininger K, Byerlee D (2011) Rising global interest in farmland: can it yield sustainable and equitable benefits? The World Bank, Washington, D.C.

European Commission (2006) COM (2006) 34, Strategia dell'UE per i biocarburanti. Bruxelles

European Commission (2008) Comunicazioni, Pacchetto clima-energia (20-20-20). Bruxelles

European Commission (2010a) COM (2010) 0811, Relazione della Commissione sul cambiamento indiretto di destinazione dei terreni correlato ai biocarburanti e ai bioliquidi. Bruxelles

European Commission (2010b) COM (2010) 2020 def, EUROPA 2020 - Una strategia per una crescita intelligente sostenibile e inclusiva. Bruxelles

FAO (2013) FAO statistical yearbook 2013 - world food and agriculture. Food and Agriculture Organization of the United Nations, Rome

FAO (2014) FAOSTAT. Available at http://faostat3.fao.org/faostat-gateway/go/to/home/E. Accessed 14 May 2014

Franco J, Levidow L, Fig D, Goldfarb L, Hönicke M, Mendonça ML (2010) Assumptions in the European Union biofuels policy: frictions with experiences in Germany, Brazil and Mozambique. J Peasant Stud 37(4):661-698

Galati A, Oguntoyinbo FA, Moschetti G, Crescimanno M, Settanni L (2014) The cereal market and the role of fermentation in cereal-based food production in Africa. Food Rev Int 30(4):317-337

Godfray H, Beddington JR, Crute IR, Haddad L, Lawrence D, Muir JF, Pretty J, Robinson S, Thomas SM, Toulmin C (2010) Food security: the challenge of feeding 9 billion people. Science 327(5967):812-818

Hall R (2011) Land grabbing in Southern Africa: the many faces of the investors rush. Rev Afr Polit Econ 38(128):194-214

International Land Coalition (2011) Tirana declaration. Tirana., p 2, Available at http://www.landcoalition.org/sites/ default/files/aom11/Tirana_Declaration_ILC_2011_ENG.pdf. Accessed 14 May 2014

Lavers T (2012) Land grab as development strategy? The political economy of agricultural investment in Ethiopia. J Peasant Stud 39(1):105-132

Liberti S (2011) Land grabbing. Come il mercato della terra crea il nuovo colonialismo. Edizioni Minimum Fax, Rome 
Longhitano D (2010) Land grabbing, agroenergie e commercio internazionale: tra teorie ed evidenze. Paper presented at the XLVII SIDEA Conference "L'agricoltura oltre la crisi", Campobasso, 22-25 September 2010., Available at http://ilo.unimol.it/sidea/images/upload/convegno_2010/paper/longhitano.pdf. Accessed 20 May 2014

Margulis ME, McKeon N, Borras SM Jr (2013) Land grabbing and global governance: critical perspectives. Globalizations 10(1):1-23

Matondi PB, Havnevik K, Beyene A (2011) Biofuels, land grabbing and food security in Africa. Zed Books, London. ISBN 978-1-84813-878-0

McMichaela P (2013) Land grabbing as security mercantilism in international relations. Globalizations 10(1):47-64

Peters GP, Minx JC, Weber CL, Edenhofer O (2011) Growth in emission transfers via international trade from 1990 to 2008. Proc Natl Acad Sci U S A 108:8903-8908

Pye O (2010) The biofuel connection-transnational activism and the palm oil boom. J Peasant Stud 37(4):851-874

Robertson B, Pinstrup-Andersen P (2010) Global land acquisition: neo-colonialism or development opportunity? Food Security 2:271-283

Rulli MC, Saviori A, D'Odorico P (2012) Global land and water grabbing. PNAS 110(3):892-897

Scheidel A, Sorman AH (2012) Energy transition and the global land rush: ultimate drivers and persistent consequences. Glob Environ Chang 22:588-595

Spieldoch A, Murphy S (2009) Agricultural land acquisition: implications for food security and poverty alleviation. In: Kugelman M, Levenstein S (eds) Land grab? the race for the world's farmland, Woodrow Wilson International Center fo Scholars, Asia program

The Land Matrix Global Observatory. International Land Coalition (ILC), Centre de Coopération Internationale en Recherche Agronomique pour le Développement (CIRAD), Centre for Development and Environment (CDE), German Institute of Global and Area Studies (GIGA) and Deutsche Gesellschaft für Internationale Zusammenarbeit (GIZ). Web. Accessed 23 May 2014

United Nations (1992a) United Nations Conference Environment and Development - UNCED. Rio de Janeiro., Available at http://sustainabledevelopment.un.org/content/documents/Agenda21.pdf. Accessed 28 May 2014

United Nations (1992b) United Nations Framework Convention on Climate Change - UNFCCC., Available at http://unfccc.int/resource/docs/convkp/conveng.pdf. Accessed 2 May 2014

United Nations (1998) Kyoto Protocol to the United Nations Framework Convention on Climate Change., Available at http://www.kyotoprotocol.com/resource/kpeng.pdf. Accessed 2 May 2014

Von Witzke H, Noleppa S (2010) EU agricultural production and trade: can more efficiency prevent increasing 'landgrabbing' outside Europe? OPERA., Available at http://np-net.pbworks.com/f/Non_Witske+(2010)+EU+agri_prod_ trade.pdf. Accessed 28 Jan 2016

White B, Borras SM, Hall R, Scoones I, Wolford W (2012) The new enclosures: critical perspectives on corporate land deals. J Peasant Stud 39(3-4):619-647

Zagema B (2011) Land and power. The growing scandal surrounding the new wave of investments in land. Oxfam., Available at http://www.oxfam.org/sites/www.oxfam.org/files/file_attachments/bp151-land-power-rightsacquisitions-220911-en_4.pdf. Accessed 14 Apr 2016

\section{Submit your manuscript to a SpringerOpen ${ }^{\circ}$ journal and benefit from:}

- Convenient online submission

- Rigorous peer review

- Immediate publication on acceptance

- Open access: articles freely available online

High visibility within the field

Retaining the copyright to your article

Submit your next manuscript at $\boldsymbol{\nabla}$ springeropen.com 